1[ 1]. byrne flood and shanahan:1[1]. connolly_et_ah 4/27/2010 9:59 AM Page 1

\title{
COMMUNICATION APPREHENSION AMONG BUSINESS AND ACCOUNTING STUDENTS IN IRELAND
}

\author{
Marann Byrne \\ Dublin City University \\ Barbara Flood \\ Dublin City University \\ and \\ Dan Shanahan
}

Dublin Institute of Technology

\begin{abstract}
Communication apprehension (CA) refers to an individual's fear of oral and/or written communication. This paper explores CA among business and accounting students in Ireland, having first established the statistical validity and reliability of the measurement instruments for use in an Irish context. An analysis of the apprehension scores shows that the level of CA reported by the students in this study is lower than some research indicates elsewhere. Contrary to previous findings, the analysis fails to show any differences in the levels of CA reported by accounting compared to other business students. Gender differences are also explored.
\end{abstract}

\section{INTRODUCTION}

Good oral and written communication skills are critical for success in today's global, dynamic business world (Roebuck, Sightler and Brush, 1995; Dearing, 1997; Messmer, 1999; Albrecht and Sack, 2000; International Federation of Accountants, 2003). Several empirical studies have highlighted the fact that employers place significant emphasis on communication skills in their hiring and promotion decisions (Deppe, Sonderegger, Stice, Clarke and Streuling, 1991; Maes, Weldy and Icenogle, 1997; Warnock and Curtis, 1997; Ulrich, Michenzi and Blouch, 2003). This has resulted in many business schools incorporating some 
form of communication skills development as part of their degree programmes (Ameen, Guffey and Jackson, 2000); however, often the desired improvement in students' communication competencies does not emerge (Fordham and Gabbin, 1996; Hassall, Joyce, Ottewill, Arquero and Donoso, 2000; Gardner, Milne, Stringer and Whiting, 2005). It is now recognised that the failure to develop appropriate communication skills may not be due to the quality of relevant education and training, but rather may result from students experiencing high levels of communication apprehension (CA). In fact, exposing students with high levels of CA to situations designed to improve their communication skills is likely to increase their anxiety and lessen their learning (Gardner et al., 2005). Consequently, Allen and Bourhis (1996) argue that it is necessary to reduce CA before communication skills can be improved.

If business and accounting academics are to be successful in designing intervention strategies that will develop students' communication capabilities, they will firstly need to gain an insight into the CA profiles of their students. Indeed, an understanding of the phenomenon of $\mathrm{CA}$ is fundamental to identifying appropriate strategies that will lead to a reduction in CA (Arquero, Hassall, Joyce and Donoso, 2007). While some research concerning CA of business and accounting students has been reported previously, little research of this type has been conducted in Ireland, despite the call for country-specific research which can evaluate CA within the relevant cultural context (Pryor, Butler and Boehringer, 2005; Arquero et al., 2007). Accordingly, the objective of this study is two-fold. Firstly, it tests the validity and reliability of two instruments, commonly employed to measure CA, for use in an Irish context. Secondly, it analyses the levels of oral and written CA reported among business and accounting students at a higher education institution in Ireland.

The remainder of the paper is structured as follows. The next section examines prior literature concerning communication apprehension generally and among business and accounting students specifically. The following section outlines the research objectives and the data collection process. The results are then presented and discussed and the paper concludes by presenting the limitations and considering the contribution of the study.

\section{COMMUNICATION APPREHENSION}

There are two general forms of communication apprehension, oral and written. Oral communication apprehension (OCA) is defined as an individual's level of fear or anxiety associated with either real or anticipated oral communication with another person or persons (McCroskey, 1978, 1984a). For an individual with high $\mathrm{CA}$, the negative feelings about communicating outweigh the perceived benefits of communicating (Stanga and Ladd, 1990). Prior research has shown that OCA has an impact on such factors as occupational choice (Daly and McCroskey, 1975), recruitment decisions (Daly, Richmond and Leth, 1979; Ayers and Crosby, 1995; Warnock and Curtis, 1997), classroom seating decisions (Daly and Suite, 1982), job satisfaction (Falcione, McCroskey and Daly, 1977; Thomas, Tymon and Thomas, 1994) and academic performance (McCroskey and Andersen, 1976; Bourhis and Allen, 1992). 
Written communication apprehension (WCA) is described as a fear of writing (Daly, 1978). Students with high WCA tend to find the experience of writing more punishing than rewarding and thus they avoid the task (Faris, Golen and Lynch, 1999). Prior studies have reported that students with high levels of WCA are unlikely to enrol in programmes or modules requiring writing skills, perform poorly in written assignments, are likely to select careers perceived to have low writing requirements, and are also likely to have high OCA (Daly and Miller, 1975a; Daly, 1978).

\section{Measuring Communication Apprehension}

McCroskey (1984b) designed the Personal Report of Communication Apprehension (PRCA) questionnaire to measure OCA. This instrument has been described as the best available measure of OCA and has been extensively employed in a wide range of research studies (Simons, Higgins and Lowe, 1995; Richmond and McCroskey, 1998; Pitt, Berthon and Robson, 2000; Borzi and Mills, 2001). Since its original development the PRCA has been refined several times resulting in its current form, which is known as the PRCA-24. The PRCA-24 measures OCA in four communication settings: one-to-one communications (dyad), group situations, meetings and public speaking, and it is possible to derive a score for each setting as well as an overall measure of OCA. The instrument contains six statements for each of the four contexts and respondents indicate their agreement to each statement using a five-point Likert scale, from $1=$ strongly agree to $5=$ strongly disagree. Twelve statements are positively worded and twelve are negatively worded. The overall measure can range from 24 to 120. Prior research with 25,000 students in 52 colleges in the United States (US) has shown that this measure has a normal distribution with a mean of 65.6 (often referred to as the US national norm) and a standard deviation of 15.3 (McCroskey, 1984b). A student with a score one standard deviation beyond the mean (80.9 or higher) is regarded as highly apprehensive, while a student with a score of one standard deviation below the mean ( 50.3 or lower) is classified as having low OCA (Kelly and Watson, 1986).

Daly and Miller (1975b) developed the Written Communication Apprehension (WCA) questionnaire to measure anxiety towards writing. This instrument (WCA-26) consists of 26 statements, some of which are framed positively and some negatively. The responses are combined together to produce a single score for writing apprehension. In a study of 3,602 undergraduate students in the US, it was found that the mean score for WCA was 75.6 with a standard deviation of 13.35 (Daly, 1978), and these values have been considered a national norm for the US in some subsequent studies. In recent studies with accounting students in the United Kingdom (UK), Spain and New Zealand, a modified version of the instrument was used (which contains 24 items and is known as the WCA-24) (Hassall et al., 2000; Gardner et al., 2005). In completing the WCA-24 an individual responds to each statement using a five-point Likert scale, from $1=$ strongly agree to $5=$ strongly disagree. This results in a range of potential scores ranging from 24 to 120 , with a projected mean of 72 . A high score, typically over 80 , indicates a high level of WCA and a score of less than 50 depicts a low level of WCA. 


\section{Communication Apprehension among Business and Accounting Students}

The increased emphasis on the importance of good communication skills in the business world has led to a number of researchers investigating the levels of CA among business students, with much of this research focusing on accounting students due to the ongoing accounting education change debate. In an early US study, Stanga and Ladd (1990) found that introductory accounting students had slightly above average levels of OCA compared to the national average. This finding was replicated by subsequent US studies and research conducted elsewhere (Simons et al., 1995 - US; Warnock and Curtis, 1997 - Ireland; Hassall et al., 2000 - UK and Spain; Gardner et al., 2005 - New Zealand; Arquero et al., 2007 - UK and Spain). However, some studies with final year accounting students showed that the students' levels of OCA were at or below the US norm (e.g. Ruchala and Hill, 1994; Fordham and Gabbin, 1996). Several researchers have also explored variations in the levels of OCA experienced by accounting students compared to those taking different business majors. In the US, Simons et al. (1995) found that accounting majors had higher OCA scores than other business majors and they had the highest scores in three of the four communication settings (group, meeting and public speaking). Similar findings have been reported with accounting students studying in the UK and Spain (Hassall et al., 2000; Arquero et al., 2007), and Ireland (Warnock, Currie and Curtis, 2005). In contrast, Borzi and Mills (2001) found that accounting majors at two US universities had significantly lower levels of OCA than non-accounting majors.

Studies exploring the impact of higher education on the levels of CA experienced by business and accounting students have yielded mixed results. In a US longitudinal study, Aly and Islam (2003) found no significant differences in the levels of OCA reported by students when beginning and completing accounting programmes. In another US study, Fordham and Gabbin (1996) concluded that the communication component of the curriculum alone was not successful in alleviating CA in students with above average levels of apprehension. Similarly, Gardner et al. (2005) found no significant differences in OCA between students in introductory, intermediate and advanced accounting courses at a New Zealand university. Hassall et al. (2000) also observed that students' OCA scores remained unchanged as they progressed through their degree programmes. In Ireland, Warnock et al. (2005) found that postgraduate accounting students exhibited very high scores for OCA at the start of their programme, but there was a significant reduction in their scores by the end of the programme, particularly in the area of public speaking.

Several studies have examined the link between levels of OCA and academic performance, but the findings have been inconclusive. Warnock and Curtis (1997) found no association between OCA and students' overall academic results. Gardner et al. (2005) also concluded that there was very little evidence of association between levels of oral apprehension and academic performance. However, the results of a study by Allen and Bourhis (1996) showed that high levels of OCA were related to lower academic achievement. Similarly, Arquero et al. (2007) reported a highly significant association between academic self-rating and OCA.

WCA has received far less attention than OCA within the business and accounting disciplines. Simons et al. (1995) found that business and accounting 
students were less apprehensive about writing than the US national norm (Daly, 1978), but that accounting majors were more apprehensive than other business majors. In another US study, Faris et al. (1999) also reported that accounting majors showed significantly greater WCA than non-accounting majors. In New Zealand, Gardner et al. (2005) found that first year accounting students reported much higher levels of WCA than other first year business students. They also identified a small but significant negative correlation between WCA and academic performance.

\section{Communication Apprehension and Gender Differences}

Prior research concerning the impact of gender on OCA has produced conflicting results. Some studies (McCroskey, 1984a; Elias, 1999) observed that female students have higher OCA than males whereas other researchers found no gender differences or, indeed, they report the opposite result (Daly and Stafford, 1984; Dwyer, 1998). This inconsistency in the findings has also been found in research with business and accounting students. Stanga and Ladd (1990) reported no differences in the levels of OCA between male and female accounting students. However, Simons et al. (1995) found that female accounting and management students were more apprehensive about oral communication (OC) than their male counterparts. Furthermore, when analysing the four communication settings they found that female students were significantly more apprehensive in meetings and public speaking situations than male students. Several other studies have also identified gender differences, with female students exhibiting significantly higher levels of OCA, especially in the areas of public speaking (presentations) and meetings (interviews) (Hassall et al., 2000; Gardner et al., 2005; Arquero et al., 2007).

In the case of WCA, some studies (Daly and Miller, 1975a; Riffe and Stacks, 1992; Elias, 1999) found that female students have lower WCA than male students, while other studies reported the opposite results or no gender differences (Cayton, 1990). Within the business and accounting disciplines, several studies have found that gender was not a significant variable in determining a student's WCA (Simons et al., 1995; Faris et al., 1999; Gardner et al., 2005; Arquero et al., 2007).

\section{RESEARCH METHOD}

\section{Objectives of the Study}

This paper explores communication apprehension among business and accounting students studying at an Irish higher education institution. Specifically, the objectives of this study are:

1. To test the validity of the PRCA-24 and the WCA-24 for use in an Irish context

2. To measure the levels of oral and written CA reported by first year business students and 
Byrne, Flood \& Shanahan

- to investigate variations in the levels of CA across the various business disciplines, with particular emphasis on accounting

- $\quad$ to identify any gender differences

In this study, accounting students are particularly identified as a subset of the full group of business students for two reasons. Firstly, the accounting education change debate, which has highlighted the need to enhance the non-technical skills of accounting students, has been raging for the past thirty years. Secondly, a large number of prior studies have either exclusively examined CA in accounting students or have isolated the performance of accounting students within studies concerning business students generally. Thus, there is a wide range of comparative data concerning CA of both business students (which includes accounting students) and accounting students separately.

\section{Data Collection}

To achieve the objectives of the study a questionnaire was designed consisting of three sections. The first section gathered information on gender and programme of study. Section two contained the PRCA-24 and the final section included the WCA24. The questionnaire was distributed to first year business and accounting students at an Irish higher education institution. Prior to completing the questionnaire the purpose of the study was explained and the students were reassured that their individual responses were confidential and would only be used for research purposes.

Table 1 presents a breakdown of the sample and the usable response rate for each programme group. Of the total respondents, 57 per cent were male and 43 per cent were female. Given the high response rate, there is no reason to suspect non-response bias.

TABLE I: POPULATION AND SAMPLE RESPONSE RATE

\begin{tabular}{lccc}
\hline Programme of Study & Population & Responses & \% Response \\
\hline Accounting and Finance & 34 & 34 & $100 \%$ \\
Business and Management & 138 & 101 & $73 \%$ \\
Marketing & 91 & 64 & $70 \%$ \\
Other Business' & 112 & 83 & $74 \%$ \\
Total & 375 & 282 & $75 \%$ \\
\hline
\end{tabular}

'Students taking one of the following bachelor business degree programmes: Information Systems Development, Retail and Services Management, or Transport and Logistics.

\section{RESULTS AND DISCUSSION}

\section{Factor Analysis and Reliability Analysis of the Instruments}

Prior research has provided substantial evidence to support both the reliability and the construct validity of the PRCA-24 in the US and elsewhere (e.g. McCroskey, Beatty, 
Kearney and Plax, 1985; Levine and McCroskey, 1990). There have also been a small number of studies with business and accounting students that have confirmed the validity and the reliability of the instrument (Pitt et al., 2000; Gardner et al., 2005). Unlike the PRCA-24, the evidence on the statistical properties of the WCA instrument is mixed. Although Daly and Miller (1975a) strongly believe that it captures a single construct, several studies have provided evidence questioning the unidimensionality of the instrument (Burgoon and Hale, 1983; Shaver, 1990; Bline, Lowe, Meixner and Nouri, 2003). Studies testing the construct validity of the WCA instrument for use with accounting and business students are scarce (Bline et al., 2003). Gardner et al. (2005) is the only study conducted with business and accounting students that examined the statistical properties of the WCA-24. When a single factor model was imposed, Gardner et al. (2005) found that 20 items had loadings greater than 0.5 and that this model explained 37 per cent of the variance. Also, the Cronbach alpha value for the 24 items was 0.92 .

The construct validity and the reliability of both PRCA-24 and WCA-24 have not been tested in any previous study for use in Ireland, thus it was necessary to conduct both factor analysis and tests concerning the internal consistency of scales. Initially, to ensure that it was appropriate to perform factor analysis on the data, a Kaiser-Meyer-Olkin (KMO) measure of sampling adequacy was first calculated. The overall KMO for both the PRCA-24 and the WCA-24 was 0.93 and each variable had an anti-image correlation in excess of 0.82 , indicating that each data set was suitable for factor analysis. The reliability of factor analysis is also dependent on an adequate sample, with a minimum of 200 cases recommended (Guilford, 1956; Gorsuch, 1983). Additionally, Bryant and Yarnold (1995) suggest that the case-tovariable ratio should be no lower than five. The sample in this study exceeds the minimum suggested by both of these criteria. Thus, factor analysis using maximum likelihood extraction was performed for both the PRCA-24 and the WCA-24. Given the anticipated correlation between the factors, the extracted factor matrix in both cases was rotated using an oblique rotation (direct oblimin) as this 'provides a more accurate and reliable representation of how constructs are likely to be related to one another' (Fabrigar, MacCallum, Wegener and Strahan, 1999, p. 282).

In the case of the PRCA-24 the factor analysis yielded four factors with an eigenvalue greater than one. The emerging four factors are those that were expected conceptually and can be clearly identified as relating to the four communication contexts: meetings, one-to-one, public speaking and groups. The full factor pattern is set out in Table 2, though only salient loadings - that is loadings in excess of 0.3 - are shown (Kline, 1994, p. 180). The four-factor solution on PRCA-24 explains 65.5 per cent of the variance, which is in line with values reported in other studies (Blue, Stratton, Donnelly, Nash and Schwartz, 1998; Pitt et al., 2000; Gardner et al., 2005). The primary loading of all 24 items is on the anticipated factors. Two items cross-load (items 6 and 9) but, as can be seen, the loading on the expected factor dominated the secondary loading for item 6 , leaving item 9 as the only item which has not emerged as strongly as expected. To determine if the instrument provided one valid composite measure of OCA, a single factor solution was requested. The resulting solution explained 46.2 per cent of the variance, and all 24 items had loadings in excess of 0.50 . This compares 
Byrne, Flood \& Shanahan

favourably to the findings of other studies that requested a single factor (Hutchinson, Neuliep and More, 1995; Gardner et al., 2005).

TABLE 2: FACTOR ANALYSIS OF PRCA-24 WITH FOUR EXTRACTED FACTORS

\begin{tabular}{|c|c|c|c|c|c|}
\hline & & \multicolumn{4}{|c|}{ Factor } \\
\hline & & $\mathbf{I}$ & II & III & IV \\
\hline I & I dislike participating in group discussions* & & & & 0.550 \\
\hline 2 & $\begin{array}{l}\text { Generally, I am comfortable while participating } \\
\text { in group discussions }\end{array}$ & & & & 0.755 \\
\hline 3 & $\begin{array}{l}\text { I am tense and nervous while participating in } \\
\text { group discussions* }\end{array}$ & & & & 0.749 \\
\hline 4 & I like to get involved in group discussions & & & & 0.750 \\
\hline 5 & $\begin{array}{l}\text { Engaging in a group discussion with new people } \\
\text { makes me tense and nervous* }\end{array}$ & & & & 0.516 \\
\hline 6 & $\begin{array}{l}\text { I am calm and relaxed while participating in } \\
\text { group discussions }\end{array}$ & 0.352 & & & 0.546 \\
\hline 7 & $\begin{array}{l}\text { Generally, I am nervous when I have to } \\
\text { participate in a meeting* }\end{array}$ & 0.834 & & & \\
\hline 8 & $\begin{array}{l}\text { Usually, I am comfortable when I have to } \\
\text { participate in a meeting }\end{array}$ & 0.897 & & & \\
\hline 9 & $\begin{array}{l}\text { I am very calm and relaxed when I am called } \\
\text { upon to express an opinion at a meeting }\end{array}$ & 0.397 & & 0.325 & \\
\hline 10 & I am afraid to express myself at meetings* & 0.334 & & & \\
\hline II & $\begin{array}{l}\text { Communicating at meetings usually makes } \\
\text { me feel uncomfortable* }\end{array}$ & 0.435 & & & \\
\hline 12 & $\begin{array}{l}\text { I am very relaxed when answering questions } \\
\text { at a meeting }\end{array}$ & 0.476 & & & \\
\hline 13 & $\begin{array}{l}\text { While participating in a conversation with } \\
\text { a new acquaintance, I feel very nervous* }\end{array}$ & & -0.588 & & \\
\hline 14 & I have no fear of speaking up in conversations & & -0.424 & & \\
\hline 15 & $\begin{array}{l}\text { Ordinarily I am very tense and nervous in } \\
\text { conversations* }\end{array}$ & & -0.922 & & \\
\hline 16 & $\begin{array}{l}\text { Ordinarily I am very calm and relaxed in } \\
\text { conversations }\end{array}$ & & -0.896 & & \\
\hline 17 & $\begin{array}{l}\text { While conversing with a new acquaintance, } \\
\text { I feel very relaxed }\end{array}$ & & -0.535 & & \\
\hline 18 & I'm afraid to speak up in conversations* & & -0.509 & & \\
\hline 19 & I have no fear of giving a speech & & & 0.712 & \\
\hline 20 & $\begin{array}{l}\text { Certain parts of my body feel very tense and } \\
\text { rigid while giving a speech* }\end{array}$ & & & 0.672 & \\
\hline 21 & I feel relaxed while giving a speech & & & 0.761 & \\
\hline 22 & $\begin{array}{l}\text { My thoughts become confused and jumbled } \\
\text { when I am giving a speech* }\end{array}$ & & & 0.668 & \\
\hline 23 & $\begin{array}{l}\text { I face the prospect of giving a speech with } \\
\text { confidence }\end{array}$ & & & 0.792 & \\
\hline 24 & $\begin{array}{l}\text { While giving a speech, I get so nervous } \\
\text { I forget facts I really know* }\end{array}$ & & & 0.628 & \\
\hline Cror & ach Alpha Value & 0.90 & 0.87 & 0.87 & 0.88 \\
\hline Cror & ach Alpha Value for PRCA-24 (total) & 0.95 & & & \\
\hline
\end{tabular}

* These items are reverse coded. 
Cronbach alpha values were then extracted to test the internal reliability of each of the scales associated with the four oral communication settings and the overall measure of OCA. As can be seen from Table 2, the alpha values for the four contexts range from 0.87 to 0.90 and the value for the global measure of OCA is 0.95. These values exceed the acceptable level of 0.7 (Nunnally and Berstein, 1994) and are similar to values reported in previous studies (Simons et al., 1995; Blue et al., 1998; Pitt et al., 2000; Gardner et al., 2005). Furthermore, the inter-correlations between the four communication settings range from 0.47 to 0.69 , providing additional support for the internal consistency of the PRCA-24.

Given the conceptual underpinnings of the WCA instrument, a one-factor solution is commonly imposed. Table 3 shows the results for the one-factor WCA model in this study. Nineteen items have loadings greater than 0.5 and the loadings for the remaining five items ranged from 0.42 to 0.50 . This model explained 39 per cent of the variance, which is slightly more than the variance explained by the one-factor model in the study by Gardner et al. (2005). The Cronbach alpha calculated on the 24 WCA items shows very high reliability with a value of 0.93 ,

TABLE 3: FACTOR ANALYSIS OF WCA-24 WITH ONE EXTRACTED FACTOR

\begin{tabular}{|c|c|c|}
\hline & & $\begin{array}{c}\text { Factor } \\
\text { I }\end{array}$ \\
\hline 1 & I avoid writing* & 0.509 \\
\hline 2 & I have no fear of my writing style being evaluated & 0.498 \\
\hline 3 & I look forward to writing down my ideas & 0.601 \\
\hline 4 & I prefer to answer numerical rather than essay questions* & 0.421 \\
\hline 5 & I like to do written work & 0.511 \\
\hline 6 & My mind seems to go blank when I start to write* & 0.560 \\
\hline 7 & Expressing ideas through writing seems to be a waste of time* & 0.557 \\
\hline 8 & I like to write my ideas down & 0.513 \\
\hline 9 & I feel confident in my ability to clearly express my ideas in writing & 0.767 \\
\hline 10 & I like to have my friends read what I have written & 0.430 \\
\hline II & I'm nervous about writing* & 0.619 \\
\hline 12 & People seem to appreciate what I write & 0.603 \\
\hline 13 & I enjoy writing & 0.720 \\
\hline 14 & I never seem to be able to clearly write down my ideas* & 0.651 \\
\hline 15 & Writing is a lot of fun & 0.499 \\
\hline 16 & I expect to do badly in courses that require written assignments* & 0.709 \\
\hline 17 & I like seeing my thoughts on paper & 0.556 \\
\hline 18 & Discussing my writing with others is an enjoyable experience & 0.464 \\
\hline 19 & I have a terrible time organising my ideas when writing an essay* & 0.589 \\
\hline 20 & When I have to write an essay I know I'm going to do poorly* & 0.719 \\
\hline 21 & It's easy for me to write good essays & 0.670 \\
\hline 22 & I don't think I write as well as most people* & 0.667 \\
\hline 23 & I don't like my written work to be evaluated* & 0.650 \\
\hline 24 & I'm no good at writing* & 0.790 \\
\hline \multicolumn{2}{|c|}{ Cronbach Alpha Value for WCA-24 } & 0.93 \\
\hline
\end{tabular}

*These items are reverse coded. 
Byrne, Flood \& Shanahan

which is well above the acceptable value of 0.7 (Nunnally and Berstein, 1994). Again, the results on the reliability of the single model are comparable to those reported by Gardner et al. (2005).

In summary, the foregoing validity and reliability analysis clearly illustrates that the PRCA-24 and WCA-24 can be confidently used to measure students' CA in an Irish setting.

\section{Communication Apprehension Scores}

Table 4 shows the overall mean scores and the standard deviations for both OCA and WCA for the full sample in comparison with the scores reported in prior studies with business students (including accounting students). Comparative data examining just the subset of accounting students are presented in Table 5. Both tables clearly show that the results for OCA and WCA for the full sample, and the accounting subset, are very similar to the findings reported in other studies. Unsurprisingly, public speaking is the oral communication context with the highest score, and students are typically most comfortable with one-to-one conversations. This pattern is consistent with the findings of most other studies (e.g. Simons et al., 1995; Gardner et al., 2005; Arquero et al., 2007)

While the findings in this study are similar to those found elsewhere, the variation in the scores of the accounting students compared to those reported in previous Irish research is noteworthy. Warnock and Curtis (1997) found that the undergraduate accounting students at an Irish university exhibited very high levels of OCA, with a score of 72.6. This is significantly higher $(p=0.00)$ than the value of 63.6 reported in the current study. This highly significant $(p=0.00)$ difference between the two studies is present for all four oral communication settings. One possible explanation for this disparity is perhaps that students today, compared to ten years earlier, have a better understanding of the importance of communication skills to a career in accounting and this is resulting in students with lower levels of CA now choosing accounting programmes, compared to previously.

One of the objectives of this study is to investigate if there is any variation in the levels of CA reported by students in different business disciplines and between males and females. Table 6 shows the mean scores for both oral and written CA by degree programme and by gender. To test for any significant differences between the programmes, and also to test for any gender differences, ANOVA (analysis of variance) tests were performed. Initially, a two-way ANOVA test was carried out to investigate any interaction between degree programme and gender on the measures of CA. No significant interaction was identified on any of the measures: group discussions $(p=0.746)$, meetings $(p=$ $0.815)$, one-to-one $(p=0.056)$, public speaking $(p=0.282)$, OCA $(p=0.197)$ and WCA $(p=0.366)$. Thus, it was possible to explore the effects of degree programme and gender separately. 
Communication Apprehension among Business and Accounting Students in Ireland

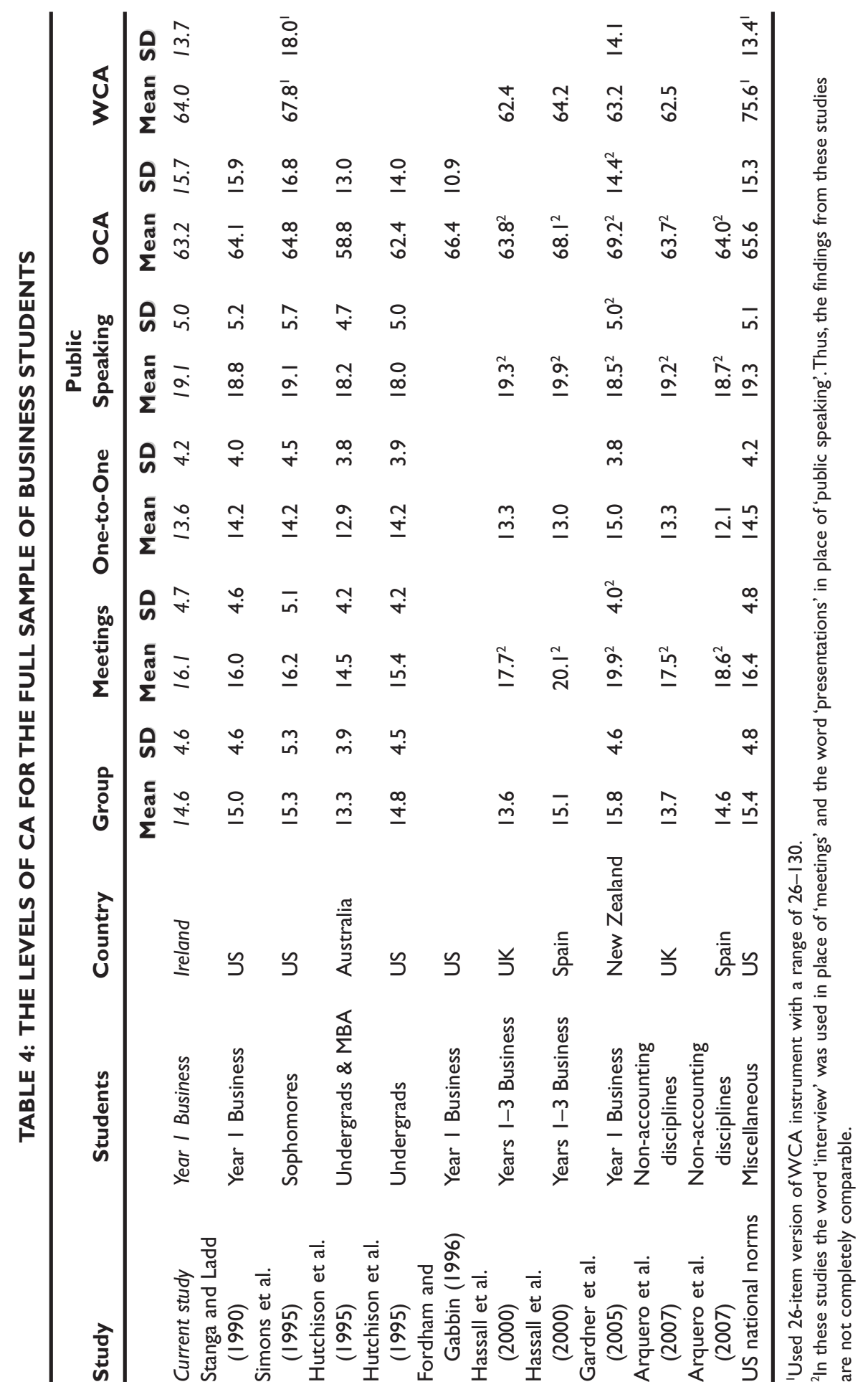


Byrne, Flood \& Shanahan

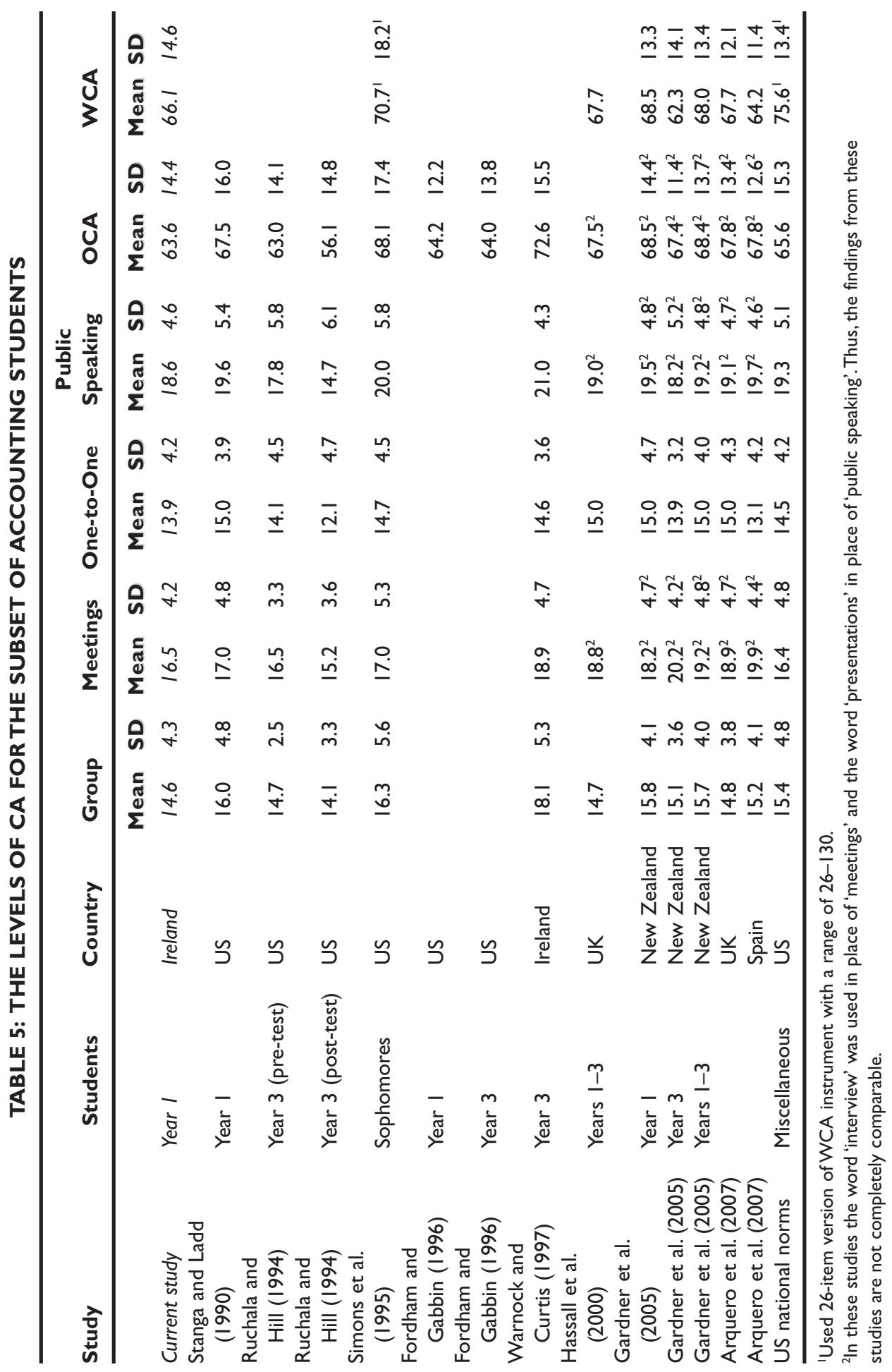


The only significant difference between the scores for students on the various degree programmes was in the level of WCA. Tukey's post-hoc test revealed that the marketing students had a significantly lower score on WCA $(p=0.03)$ than the students on the other degree programmes. The low level of variation between the different groups is contrary to the results reported in most studies with business students (Stanga and Ladd, 1990; Arquero et al., 2007). In particular, prior studies have typically shown that accounting students are significantly more apprehensive than other business students (Stanga and Ladd, 1990; Simons et al., 1995; Arquero et al., 2007), but this was not found in the current study. While at first this surprised us, when we extracted and examined the grades achieved by the students in their Leaving Certificate English examination, which gives some measure of their previous communication competence, it was clear that the scores of the accounting students were not significantly different to the grades achieved by the students on the other programmes. It is also possible that there are other reasons which explain why the accounting students in this study have lower apprehension than accounting students in other studies. For example, the accounting students in this study take most of their classes separately from the other business students. The small class size of just 34 students may result in a more relaxed and supportive environment, thereby generating lower levels of apprehension than if they were in a larger class, which may have been the case in previous studies. Furthermore, in recent years the accounting profession in Ireland has noticeably

TABLE 6: MEAN CA SCORES BY DEGREE PROGRAMME AND BY GENDER

\begin{tabular}{llcccccc}
\hline Programme & Gender & Group & Meetings & $\begin{array}{c}\text { One-to- } \\
\text { One }\end{array}$ & $\begin{array}{c}\text { Public } \\
\text { Speaking }\end{array}$ & OCA & WCA \\
\hline Full Sample & Male & 14.63 & 15.75 & 13.38 & 18.23 & 62.03 & 62.56 \\
& Female & 14.60 & 16.65 & 13.97 & 20.34 & 64.85 & 65.80 \\
& Total & 14.62 & 16.14 & 13.63 & 19.13 & 63.19 & 63.96 \\
Accounting & & & & & & & \\
and Finance & Male & 13.89 & 15.53 & 12.16 & 17.11 & 58.68 & 62.95 \\
& Female & 15.53 & 17.73 & 16.00 & 20.53 & 69.80 & 70.13 \\
& Total & 14.62 & 16.50 & 13.85 & 18.62 & 63.59 & 66.12 \\
Business & & & & & & & \\
and Managementen & Male & 15.10 & 15.93 & 13.42 & 17.85 & 62.05 & 60.61 \\
& Female & 15.18 & 16.67 & 14.67 & 21.18 & 67.63 & 66.72 \\
& Total & 15.13 & 16.22 & 13.90 & 19.15 & 64.21 & 62.99 \\
Marketing & Male & 13.76 & 15.03 & 13.03 & 18.45 & 61.18 & 60.79 \\
& Female & 13.69 & 15.45 & 12.48 & 19.00 & 59.76 & 60.23 \\
Other & Total & 13.72 & 15.25 & 12.75 & 18.74 & 60.46 & 60.50 \\
Business' & & & & & & & \\
& Male & 14.84 & 16.04 & 14.02 & 19.00 & 63.81 & 66.18 \\
& Female & 14.38 & 17.33 & 13.70 & 20.59 & 63.67 & 68.06 \\
& Total & 14.65 & 16.56 & 13.90 & 19.63 & 63.76 & 66.96 \\
\hline
\end{tabular}

'Students taking one of the following bachelor business degree programmes: Information Systems Development, Retail and Services Management, or Transport and Logistics. 
Byrne, Flood \& Shanahan

increased its level and type of advertising for the purposes of encouraging school leavers and graduates to consider accounting careers. There has been considerable emphasis on eliminating the traditional accountant's stereotype and portraying accounting as offering a business-focused career with great opportunity for success across sectors (e.g. Chartered Accountants Ireland (CAI) are using innovative radio and cinema advertisements). This may have resulted in attracting a broader set of students into accounting programmes.

With regard to gender differences, the analysis revealed significant differences in public speaking $(\mathrm{p}=0.000)$. Consistent with the findings of other studies, female students exhibit significantly higher levels of anxiety in formal oral communication settings than their male counterparts (Simons et al., 1995; Hassall et al., 2000; Gardner et al., 2005; Arquero et al., 2007). There were no gender differences relating to WCA, which is also consistent with several prior studies (Simons et al., 1995; Faris et al., 1999; Gardner et al., 2005; Arquero et al., 2007).

To enrich the findings of the study, the data were analysed further by deriving a grouped frequency distribution for OCA and WCA scores (Table 7). Students were allocated to the high group if their CA score was greater than 80 and to the low group if their score was less than 50 (approximately 1 standard deviation above and below the widely accepted average norms for both 24-item versions of the instruments). The remaining students were classified as having average CA scores.

TABLE 7: FREQUENCY DISTRIBUTION OF THE OCA AND WCA SCORES

\begin{tabular}{llcccc}
\hline Programme & Level of CA & \multicolumn{2}{c}{ OCA } & \multicolumn{2}{c}{ WCA } \\
\hline \multirow{4}{*}{ Full Sample } & & Number & $\%$ & Number & $\%$ \\
& High $>80$ & 40 & 15 & 33 & 12 \\
& Average $50-80$ & 176 & 67 & 203 & 75 \\
& Low $<50$ & 48 & 18 & 35 & 13 \\
Accounting and Finance & High $>80$ & & & & \\
& Average 50-80 & 22 & 64 & 25 & 73 \\
& Low $<50$ & 7 & 21 & 4 & 12 \\
Business and Management & High $>80$ & 18 & 18 & 10 & 10 \\
& Average 50-80 & 63 & 65 & 75 & 76 \\
& Low $<50$ & 17 & 17 & 14 & 14 \\
& & & & & \\
Marketing & High $>80$ & 7 & 12 & 4 & 7 \\
& Average 50-80 50 & 36 & 63 & 43 & 71 \\
& Low $<50$ & 14 & 25 & 13 & 22 \\
& & & & & \\
Other Business & High $>80$ & 10 & 13 & 14 & 18 \\
& Average 50-80 & 55 & 74 & 59 & 77 \\
& Low $<50$ & 10 & 13 & 4 & 5
\end{tabular}

'Students taking one of the following bachelor business degree programmes: Information Systems Development, Retail and Services Management, or Transport and Logistics. 
Table 7 shows that 15 per cent of the full sample report high OCA and 18 per cent report low OCA. These percentages are better than those anticipated by McCroskey (1984b), who stated that normally 16 per cent of the population are highly apprehensive and 16 per cent report very low apprehension. The percentage of students experiencing high OCA is also considerably lower than the percentage reported by Stanga and Ladd (1990), who found that 19 per cent of accounting students in their study were highly apprehensive. In the case of WCA, 12 per cent of the full sample experience high apprehension and 13 per cent report low apprehension. Interestingly, when the frequency analysis is examined by class group, the accounting students do not have the largest percentage in the high OCA or high WCA categories. This may indicate that, as contended previously when comparing the accounting students in this study to the earlier Irish research, the communication confidence of students attracted to accounting programmes may be changing.

It is reasonable to contend that this study has contributed to enhancing business educators' understanding of communication apprehension. Nonetheless, further research is needed to aid the development of appropriate strategies to address CA among students. In particular, there is a clear need to conduct qualitative research with students who have varying levels of CA in order to gain insights into the antecedents and facets of CA. Such qualitative studies could explore students' educational and social background, their prior communication experiences and their perceptions of communication situations and activities, and could also monitor their reactions to skills training and interventions.

\section{CONCLUSIONS}

This study has confirmed the validity and reliability of the PRCA-24 and the WCA-24 for the purposes of measuring both oral and written CA in an Irish setting. Additionally, the study has provided evidence of the level of both oral and written CA reported by students from a variety of business programmes at a higher education institution in Ireland. In terms of the interpretation of the results in comparison to those conducted in other countries, it is interesting to note that accounting students in this study did not report significantly different levels of apprehension compared to other business students and, indeed, reported scores that were typically lower than those of accounting students in other studies. This may mean that accounting educators and the profession in Ireland have successfully conveyed the message that a career in accounting involves high levels of both written and oral communication and is not a career for those who wish to avoid communication situations. In terms of exploring gender differences, this study, like many previous studies, reported higher levels of fear among female students regarding public speaking.

As with all research, this study has certain limitations. Firstly, the data were collected from only one higher education institution and thus care must be taken in drawing any general conclusions. Secondly, the study used self-report instruments to gather data on students' levels of CA. Although such instruments are very widely used they do suffer from the possibility that respondents may not accurately report their true views. 
Byrne, Flood \& Shanahan

In conclusion, this study has rigorously tested the validity and reliability of two common apprehension instruments for use in an Irish context. Furthermore, it has provided a useful insight into Irish students' levels of communication apprehension. In so doing, it provides a relevant benchmark for further Irish studies and for comparisons with studies conducted in other countries.

\section{REFERENCES}

Albrecht, W. and Sack, R. (2000). Accounting Education: Charting the Course through a Perilous Future, Accounting Education Series, Sarasota, FL: American Accounting Association. Allen, M. and Bourhis, J. (1996). The Relationship of Communication Apprehension to Communication Behaviour: A Meta-Analysis, Communication Quarterly, Vol. 44, No. 2, pp. 214-226.

Aly, I. and Islam, M. (2003). Audit of Accounting Programs on Oral Communication Apprehension: A Comparative Study among Accounting Students, Managerial Auditing Journal, Vol. 18, No. 9, pp. 751-760.

Ameen, E., Guffey, D. and Jackson, C. (2000). Silence is Not Golden: Further Evidence of Oral Communication Apprehension in Accounting Majors, Advance in Accounting Education: Teaching and Curriculum Innovations, Vol. 3, pp. 85-105.

Arquero, J., Hassall, T., Joyce, J. and Donoso, J. (2007). Accounting Students and Communication Apprehension: A Study of Spanish and UK Students, European Accounting Review, Vol. 16, No. 2, pp. 299-322.

Ayers, J. and Crosby, S. (1995). Two Studies Concerning the Predictive Validity of the Personal Report of Communication Apprehension in Employment Interviews, Communication Research Reports, Vol. 12, No. 2, pp. 145-151.

Bline, D., Lowe, D., Meixner, W. and Nouri, H. (2003). Measurement Data on Commonly Used Scales To Measure Oral And Writing Communication Apprehensions, Journal of Business Communication, Vol. 40, No. 4, pp. 266-288.

Blue, A., Stratton, T., Donnelly, M., Nash, P. and Schwartz, R. (1998) Students' Communication Apprehension and Its Effects on PBL Performance, Medical Teacher, Vol. 20, No. 3, pp. 217-221.

Borzi, M. and Mills, T. (2001). Communication Apprehension in Upper Level Accounting Students: An Assessment of Skill Development, Journal of Education for Business, Vol. 66, No. 4, pp. 193-198.

Bourhis, F. and Allen, M. (1992). Meta-Analysis of the Relationship between Communication Apprehension and Cognitive Performance, Communication Education, Vol. 41, No. 1, pp. 68-76.

Burgoon, J. and Hale, J. (1983). A Research Note on the Dimensions of Communication Reticence, Communications Quarterly, Vol. 31, No. 3, pp. 238-248.

Bryant, F. and Yarnold, P. (1995). Principal Components Analysis and Exploratory and Confirmatory Factor Analysis, in L. Grimm. and P. Yarnold (eds.), Reading and Understanding Multivariate Analysis, Washington, DC: American Psychological Association Books.

Cayton, M. (1990). What Happens When Things Go Wrong: Women and Writing Blocks, Journal of Advanced Composition, Vol. 10, No. 2, pp. 321-337.

Daly, J. (1978). Writing Apprehension and Writing Intensity in Business and Industry, Journal of Educational Research, Vol. 72, No. 1, pp. 10-14.

Daly, J. and McCroskey, J. (1975). Occupational Desirability and Choice as a Function of Communication Apprehension, Journal of Counselling Psychology, Vol. 22, No. 4, pp. 309-313. 
Daly, J. and Miller, M. (1975a). Further Studies on Writing Apprehension: SAT Scores, Success Expectations, Willingness to Take Advanced Courses and Sex Differences, Research in the Teaching of English, Vol. 9, No. 3, pp. 250-256.

Daly, J. and Miller, M. (1975b). The Empirical Development of an Instrument to Measure Writing Apprehension, Research in the Teaching of English, Vol. 9, No. 3, pp. 242-249.

Daly, J., Richmond, V. and Leth, S. (1979). Social Communicative Anxiety and the Personnel Selection Process: Testing the Similarity Effect in Selection Decisions, Human Communication Research, Vol. 6, No. 1, pp. 18-32.

Daly, J. and Stafford, I. (1984). Correlates and Consequences of Social-Communicative Anxiety, in J. Daly and J. McCroskey (eds.), Avoiding Communication: Shyness, Reticence and Communication Apprehension, Beverley Hills, CA: Sage.

Daly, J. and Suite, A. (1982). Classroom Seating Choice and Teacher Perceptions of Students, Journal of Experimental Education, Vol. 50, No. 2, pp. 64-69.

Dearing, R. (1997). Report on the National Committee of Inquiry into Higher Education, London: Her Majesty's Stationery Office.

Deppe, L., Sonderegger, E., Stice, J., Clark, D. and Streuling, G. (1991). Emerging Competencies for the Practice of Accountancy, Journal of Accounting Education, Vol. 9, No. 2, pp. 257-290.

Dwyer, K. (1998). Communication Apprehension and Learning Style Preference: Correlations and Implications for Teaching, Communication Education, Vol. 47, No. 2, pp. 137-150.

Elias, R. (1999). An Examination of Non-Traditional Accounting Students' Communication Apprehension and Ambiguity Tolerance, Journal of Education for Business, Vol. 75, No. 1, pp. 38-41.

Fabrigar, L., MacCallum, R., Wegener, D. and Strahan, E. (1999). Evaluating the Use of Exploratory Factor Analysis in Psychological Research, Psychological Methods, Vol. 4, No. 3, pp. 272-299.

Falcione, R., McCroskey, J. and Daly, J. (1977). Job Satisfaction as a Function of Employees' Communication Apprehension, Self-Esteem, and Perceptions of Their Immediate Supervisors, in B. Ruben (ed.), Communication Yearbook 1, New Brunswick, NJ: Transaction Books.

Faris, K., Golen, S. and Lynch, D. (1999). Writing Apprehension in Beginning Accounting Majors, Business Communication Quarterly, Vol. 62, No. 2, pp. 9-21.

Fordham, D. and Gabbin, A. (1996). Skills Versus Apprehension: Empirical Evidence on Oral Communication, Business Communication Quarterly, Vol. 59, No. 3, pp. 88-97.

Gardner, C., Milne, M., Stringer, C. and Whiting, R. (2005). Oral and Written Communication Apprehension in Accounting Students: Curriculum Impacts and Impacts on Academic Performance, Accounting Education: An International Journal, Vol. 14, No. 3, pp. 313-336.

Gorsuch, R.L. (1983). Factor Analysis (Second Edition), Hillsdale, NJ: Lawrence Erlbaum.

Guilford, J.P. (1956). Psychometric Methods, New York, NY: McGraw-Hill.

Hassall, T., Joyce, J., Ottewill, R., Arquero, J. and Donoso, J. (2000). Communication Apprehension in UK and Spanish Business and Accounting Students, Education and Training, Vol. 42, No. 2, pp. 93-100.

Hutchinson, K., Neuliep, J. and More, E. (1995). Communication Apprehension Across Cultures: A Test of the PRCA-24 and Comparisons Between Australia and the United States, Australian Journal of Communication, Vol. 22, No. 2, pp. 59-69.

International Federation of Accountants (IFAC) (2003). International Education Standard (IES) 3 Professional Skills Content, New York, NY: IFAC. 
Byrne, Flood \& Shanahan

Kelly, L. and Watson, K. (1986). Speaking with Confidence and Skill, New York, NY: Harper Row.

Kline, P. (1994). An Easy Guide to Factor Analysis, London: Routledge.

Levine, T. and McCroskey, J. (1990). Measuring Trait Communication Apprehension: A Test of Rival Measurement Models of the PRCA-24, Communication Monograph, Vol. 57, No. 1, pp. 62-72.

Maes, J., Weldy, T. and Icenogle, M. (1997). A Managerial Perspective: Oral Communication Competency is Most Important for Business Students in the Workplace, Journal of Business Communication, Vol. 34, No. 1, pp. 67-80.

McCroskey, J. (1978). Validity of the PRCA as an Index of Oral Communication Apprehension, Communication Monograph, Vol. 45, No. 3, pp. 192-203.

McCroskey, J. (1984a). The Communication Apprehension Perspective, in J. Daly and J. McCroskey (eds.), Avoiding Communication: Shyness, Reticence and Communication Apprehension, Beverly Hills, CA: Sage.

McCroskey, J. (1984b). Self-Report Measurement, in J. Daly and J. McCroskey (eds.), Avoiding Communication: Shyness, Reticence and Communication Apprehension, Beverly Hills, CA: Sage.

McCroskey, J. and Andersen, J. (1976). The Relationship between Communication Apprehension and Academic Achievement among College Students, Human Communication Research, Vol. 3, No. 1, pp. 73-81.

McCroskey, J., Beatty, M., Kearney, P. and Plax, T. (1985). The Content Validity of the PRCA-24 as a Measure of Communication Apprehension across Communication Contexts, Communication Quarterly, Vol. 33, No. 3, pp.165-173.

Messmer, M. (1999). Skills for a New Millennium, Strategic Finance, Vol. 81, No. 2, pp. 10-12.

Nunnally, J. and Berstein, I. (1994). Psychometric Theory (Third Edition), New York, NY: McGraw-Hill.

Pitt, L., Berthon, P. and Robson, M. (2000). Communication Apprehension and Perceptions of Salesperson Performance: A Multinational Perspective, Journal of Managerial Psychology, Vol. 15, No. 1, pp. 68-86.

Pryor, B., Butler, J. and Boehringer, K. (2005). Communication Apprehension and Cultural Context: A Comparison of Communication Apprehension in Japanese and American Students, North American Journal of Psychology, Vol. 7, No. 2, pp. 247-252.

Richmond, V. and McCroskey, J. (1998). Communication: Apprehension, Avoidance and Effectiveness, Needham Heights, MA: Allyn and Bacon.

Riffe, D. and Stacks, D. (1992). Student Characteristics and Writing Apprehension, Journalism Educator, Vol. 47, No. 2, pp. 39-49.

Roebuck, D., Sightler, K. and Brush, C. (1995). Organisational Size, Company Type, and Position Effects on the Perceived Importance of Oral and Written Communication Skills, Journal of Managerial Issues, Vol. 7, No. 1, pp. 99-115.

Ruchala, L. and Hill, J. (1994). Reducing Accounting Students' Oral Communication Apprehension: Empirical Evidence, Journal of Accounting Education, Vol. 12, No. 4, pp. 283-303.

Shaver, J. (1990). Reliability and Validity of Measures of Attitudes toward Writing and toward Writing with the Computer, Written Communication, Vol. 7, No. 3, pp. 375-392.

Simons, K., Higgins, M. and Lowe, D. (1995). A Profile of Communication Apprehension in Accounting Majors: Implications for Teaching and Curriculum Revision, Journal of Accounting Education, Vol. 13, No. 2, pp. 159-176. 
Communication Apprehension among Business and Accounting Students in Ireland

Stanga, K. and Ladd, R. (1990). Oral Communication Apprehension in Beginning Accounting Majors: An Exploratory Study, Issues in Accounting Education, Vol. 5, No. 2, pp. 180-194.

Thomas, G., Tymon, W. and Thomas, K. (1994). Communication Apprehension, Interpretive Styles, Preparation and Performance in Oral Briefing, Journal of Business Communication, Vol. 31, No. 4, pp. 311-326.

Ulrich, T., Michenzi, A. and Blouch, W. (2003). CPAs Assess the Development of Professional Skills of Recent Accounting Graduates, Journal of the Academy of Business Education, Vol. 4, Spring, pp. 126-137.

Warnock, K., Currie, J. and Curtis, E. (2005). Challenging the Stereotype: Reducing Communication Apprehension in Accounting Students, paper presented at the Irish Accounting and Finance Annual Conference, University of Limerick, 14-15 April 2005.

Warnock, K. and Curtis, E. (1997). Oral Communication Apprehension: A Preliminary Study of Accounting Students, paper presented at the Irish Accounting and Finance Annual Conference, Dublin City University, 8-9 May 1997. 